\title{
STRATEGI PEMASARAN PRODUK GEOTEXTILE DI PERUSAHAAN X
}

\author{
Alvin Andrew Alim \\ Program Studi Magister Manajemen Universitas Tarumanagara \\ alvingalaxies@gmail.com \\ Anas Lutfi \\ Program Studi Magister Manajemen Universitas Tarumanagara
}

Masuk : 07-06-2020, revisi : 28-06-2020 diterima untuk diterbitkan : 29-06-2020

\begin{abstract}
Company $\mathrm{X}$ is a company engaged in the textile industry and produces a product called pp woven bag. Although it was only established in 2016. This research was conducted to provide input to Company $\mathrm{X}$ to be able to strengthen its market share and also look for opportunities regarding geotextile products and segments. The research method used in the writing of this thesis is SWOT analysis and five competitive forces to identify strengths, weaknesses, as well as opportunities, threats and competition in the industry. Then Develop strategies and tactics for company $\mathrm{X}$ using segmenting, targeting, positioning (STP) and marketing mix. The results of this study are the highest segments in the construction of highways and toll roads because they have the highest needs, and need to make Geotextile products of type 300 and 350 GSM to be able to strengthen its market share and create new products such as jumbo bags that require machines and similar raw materials for the production process so that they do not have dependency in infrastructure. Then need to create a marketing place in big cities to be able to strengthen relationships with consumers and provide information to potential customers about the product, product quality, and price. Another thing that can be done is to create a strategy in the form of a loyalty program to make it easier for consumers to make purchases because of the high cost and product needs that make some companies have difficulty buying Geotextile products.
\end{abstract}

Abstrak: Perusahaan X merupakan perusahaan yang bergerak di bidang industri tekstil dan menghasilkan produk yang bernama pp woven bag. Meskipun baru berdiri pada Tahun 2016. Penelitian ini dilakukan untuk memberikan masukan kepada Perusahaan X untuk dapat memperkuat market sharenya dan juga mencari peluang mengenai produk geotextile dan segmen. Adapun metode penelitian yang dipergunakan dalam penulisan karya akhir ini adalah SWOT analisis dan five competitive forces untuk mengidentifikasi kekuatan, kelemahan, serta peluang, ancaman dan persaingan di industri tersebut. Kemudian Menyusun strategi dan taktik untuk perusahaan X menggunakan segmenting, targeting, positioning (STP) dan marketing mix. Hasil dari penelitian ini adalah segmen yang paling tinggi berada pada pembangunan jalan raya dan jalan tol dikarenakan memiliki kebutuhan yang paling tinggi, serta perlu membuat produk Geotextile jenis 300 dan 350 GSM untuk dapat memperkuat market sharenya dan menciptakan produk baru seperti jumbo bag yang memerlukan mesin dan bahan baku yang serupa untuk proses produksinya sehingga tidak memiliki ketergantungan dibidang infrastruktur. Kemudian perlu membuat tempat pemasaran di kota - kota besar untuk dapat memperkuat hubungan dengan konsumen dan memberikan informasi kepada calon konsumen tentang produk, kualitas produk, dan harga. Hal lain yang dapat dilakukan adalah menciptakan strategi berupa program loyalty untuk dapat mempermudah konsumen dalam melakukan pembelian dikarenakan biaya dan kebutuhan produk yang tinggi menjadikan beberapa Perusahaan kesulitan dalam membeli produk Geotextile.

Keywords: SWOT Analisis, Five Competitive Forces, STP, Marketing Mix, Strategi Pemasaran 


\section{PENDAHULUAN}

Perkembangan industri saat ini semakin maju, hal tersebut dibuktikan dengan munculnya industri non migas yang bergerak dibidang pengolahan biji plastik. Salah satu bidang tersebut adalah bidang yang dibutuhkan masyarakat adalah pembangunan infrastruktur dengan menggunakan plastik. Selain itu geotextile memiliki keuntungan dibidang non infrastruktur.

PT X adalah perusahaan yang bergerak dibidang industri biji plastik dimana salah satu hasil produksi nya adalah geotextile woven. Geotextile merupakan hasil dari pengolahan polyprophilene digunakan untuk stabilisasi menyeimbangkan beban dari atas ke lapisan tanah dibawahnya sehingga dapat menghindari terjadinya penurunan tanah setempat. Melihat berbagai keuntungan yang ada, peneliti berupaya untuk memperluas dan mencari peluangpeluang yang berkemungkinan untuk membantu pemasaran geotextile di Indonesia.

\section{Tujuan Penelitian}

Melihat berbagai keuntungan yang ada, peneliti berupaya untuk memperluas pemasaran geotextile di Indonesia. Melalui tesis ini peneliti bersama PT. X berusaha mengidentifikasi strategi yang tepat dalam memasarkan produk geotextile dan menentukan pasar yang dapat dijadikan sebagai peluang penjualan produk geotextile.

\section{TINJAUAN PUSTAKA}

Strategi pemasaran adalah gambar besar yang memperlihatkan hal-hal yang akan dilakukan perusahaan dalam pasar tertentu. Ada dua bagian yang diperlukan [1]:

1. Pasar target, yaitu sekelompok konsumen yang agak homogen (serupa), yang akan dihimbau perusahaan.

2. Bauran pemasaran, yaitu sejumlah variabel yang dapat dikendalikan, yang digabungkan dengan perusahaan untuk memenuhi kelompok target”.

Model strategi pemasaran adalah suatu kerangka kerja yang melibatkan sejumlah aktivitas yang akan dilakukan oleh sebuah organisasi, dengan cara bagaimana dan kapan aktivitas tersebut akan dilakukan, sehingga organisasi tersebut mampu menawarkan sejumlah manfaat yang unggul seperti yang diinginkan pelanggannya dan membuat posisi organisasi tersebut terbangun secara tepat dalam pikiran pelanggannya, yang pada akhirnya menghasilkan keuntungan bagi organisasi tersebut seperti yang diharapkan [2].

1. Faktor Eksternal

Faktor eksternal adalah Faktor - faktor diluar kendali yang mempengaruhi pilihan perusahaan mengenai arah dan tindakan, yang pada akhirnya juga mempengaruhi struktur orgnaisasi dan proses internalnya.

2. Five Competitive Forces

Alat atau metode yang digunakan oleh penulis adalah porter's five forces analysis yang berguna untuk memahami dimana letak kekuatan perusahaan dalam menghadapi situasi persaingan didunia bisnis [3].

3. Faktor Internal

Faktor internal merupakan pengidentifikasian terhadap faktor-faktor yang menjadi kekuatan dan kelemahan suatu perusahaan.

4. Analisis Eksternal - Internal

Apabila telah dianalisis faktor-faktor internal dan eksternalnnya, dan kemudian diketahui apakah merupakan kekuatan atau kelemahan dan apakah menjadi ancaman atau peluang. Maka selanjutnya dilakukan analisa untuk menentukan strategi yang tepat dalam menyusun strategi pemasaran kedepannya.

5. Strategi Pemasaran

Unsur - unsur utama pemasaran dapat diklasifikasikan menjadi tiga kelompok besar, yaitu [4]:

a. Segmentation: Segmentation atau segmentasi adalah upaya memetakan atau memilahmilahkan konsumen sesuai persamaan di antara mereka. 
b. Targeting: merupakan sebuah sasaran, siapa yang dituju. Dalam menentukan targeting maka dilakukan beberapa survey untuk dapat mengetahui keadaan pasar nantinya, agar ketika proses pemasaran tidak salah sasaran.

c. Positioning: Positioning adalah image atau citra yang terbentuk di benak seorang konsumen dari sebuah nama perusahaan atau produk.

6. Taktik Pemasaran

Unsur taktik pemasaran dikelompokan menjdi dua proses, yaitu sebagai berikut :

a. Diferensiasi: Taktik diferensiasi berkaitan dengan cara yang ditempuh oleh pemasar dalam membangun strategi pemasarannya, dengan memberikan keunikan dari produk/jasa yang ditawarkannya, yang membedakannya dari produk/jasa yang ditawarkan oleh pesaing.

b. Marketing Mix : Marketing mix adalah seperangkat alat pemasaran yang digunakan oleh perusahaa untuk mencapai tujuan pemasarannya pada pasar sasaran.

\section{METODOLOGI PENELITIAN}

Tahap pengumpulan dan pengolahan data dilakukan dengan cara wawancara dan melihat langsung di lapangan. Secara jelas tahap ini dibagi menjadi beberapa langkah yaitu sebagai berikut.

1. Penelitian diawali dengan mengidetifikasi masalah yang terdapat di perusahaan dan merumuskan permasalahan berdasarkan masalah - masalah yang akan di teliti.

2. Kemudian menentukan tujuan penelitian untuk menjawab permasalahan yang telah dirumuskan

3. Selanjutnya melakukan studi literature yaitu dengan melakukan pencarian terhadap berbagai sumber tertulis, baik berupa buku - buku, arsip, majalah, artikel dan jurnal atau dokumen - dokumen yang relevan dengan permasalahan yang diteliti.

4. Lalu memulai melakukan analisis terhadap perusahan dan industri tersebut dengan cara analisis internal dan eksternal perusahaan serta analisis five porter.

5. Kemudian menyusun strategi dan taktik yang akan digunakan guna menghadapi persaingan. Strategi yang digunakan adalah STP (segmenting, targeting, positioning) untuk menentukan segmen yang tepat

6. Selanjutnya menentukan taktik marketing mix sehingga meningkatkan efektifitas dalam memasarkan produk berdasarkan data yang telah dikumpulkan geotextile. Lalu taktik yang berikutnya adalah penjualan untuk menciptakan hubungan jangka panjang, komunikasi yang lancar dan SDM yang handal.

\section{HASIL DAN PEMBAHASAN}

Hasil dan pembahasan menggunakan analisis internal dan eksternal untuk mengetahui bagaimana keadaan perusahaan serta peluang dan ancaman diindustri tersebut. Kemudian analisis menggunakan five competitive forces untuk mengetahui persaingan di industri itu. Setelah itu Menyusun strategi menggunakan segementing, targeting, positioning dan taktik menggunakan marketing mix dan diferensiasi produk.

\section{Five Competitive Forces}

Pemain baru dapat masuk kedalam industri tersebut dengan 2 cara yaitu menjadi distributor dari perusahaan asing atau melakukan produksi sendiri. Untuk dapat menjadi produsen sendiri dibidang ini sangatlah sulit dikarenakan adanya barrier to entry yang terbilang tinggi, diantaranya adalah :

a. Capital requirement, dikarenakan alat yang digunakan untuk melakukan tes kualitas daya tarik terhadap produk tergolong tinggi.

b. Government policy, yaitu kebijakan mengenai kualitas produksi yang harus memiliki standar nasional Indonesia (SNI). 
c. Cost Disadvantages independent of Scale. Ketika perusahaan mempunyai alat produksi canggih yang telah dimodifikasi serta alat penguji kualitas sendiri tentunya hal ini akan memberikan keunggulan tersendiri bagi perusahaan tersebut.

d. Economic of scale, yaitu ketika perusahaan memproduksi barang dengan jumlah besar tentunya akan menekan biaya produksi dari barang tersebut.

Untuk sebelumnya memang ada distributor, yaitu ketika belum ada perusahaan di Indonesia yang memproduksi produk geotextile sehingga mengharuskan mengimpor produk geotextile dari China yang merupakan produksi terbesar di Asia. Tetapi hal ini menimbulkan beberapa masalah berupa kualitas yang tidak menentu dan susahnya melakukan pengecekan mengenai kualitas produk.

Untuk bahan baku tidaklah memiliki ketergantungan karena bahan baku utamanya yang berupa biji plastik dijual oleh beberapa produsen dengan harga yang hampir sama. Kemudian supplier untuk bahan baku biji plastik tidaklah sulit ditemukan di Indonesia dan memiliki kualitas yang baik.

Untuk konsumen dapat dilihat dari 2 pihak yaitu konsultan merangkap kontraktor dan juga kontraktor yang membeli langsung tanpa perantara.

a. Dari sisi konsultan merangkap kontraktor, Untuk konsultan merangkap sebagai kontraktor biasanya adalah perusahaan - perusahaan dalam skala besar

b. Dari Sisi Kontraktor, untuk kontraktor biasanya adalah perusahaan dalam skala menengah kebawah

Produk Geotextile di Indonesia masih mengalami perkembangan hingga sekarang ini, sehingga belum terlihat adanya substitusi terhadap produknya. Tetapi hal ini bukan berarti produk geotextile tidak akan menghadapi yang namanya produk substitusi.

Untuk kedepannya, akan muncul produk lain yang menggantikan geotextile dari segi fungsi, kualitas dan keunikannya dimana hal ini sangat mungkin terjadi. Persaingan di industri ini cukup sengit dikarenakan perusahaan ini adalah salah satu perusahaan dengan kualitas yang sangat baik dan juga teknologi yang dimiliki mulai dari jumlah mesin, kapasitas produksi, laboratorium untuk kualitas produk. Untuk pangsa pasar geotextile di Indonesia dapat dilihat pada Gambar 1.

2. Analisis SWOT

Dilihat dari teknologinya, perusahaan ini memiliki puluhan mesin sehingga dapat memproduksi dalam jumlah yang besar. Kemudian teknologi yang canggih yang telah dimodifikasi sehingga menghasilkan benang dengan kualitas yang sangat baik karena yang paling diperhatikan oleh konsumen adalah kualitas barang tersebut.

Produk geotextile memiliki pangsa pasar yang besar yaitu dibagian infrastruktur yang dapat dilihat pada Gambar 2 tetapi hal ini menjadikan ketergantungan akan adanya proyek.

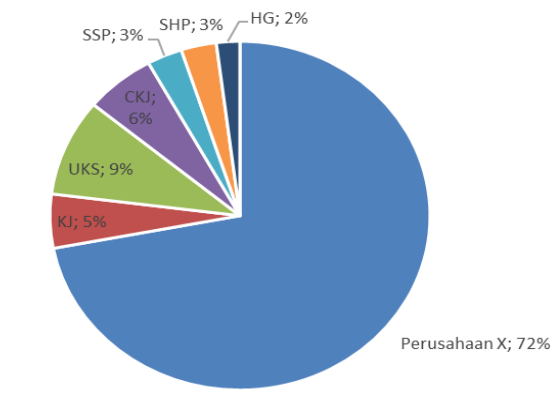

Gambar 1

Pangsa Pasar Perusahaan Geotextile di Indonesia

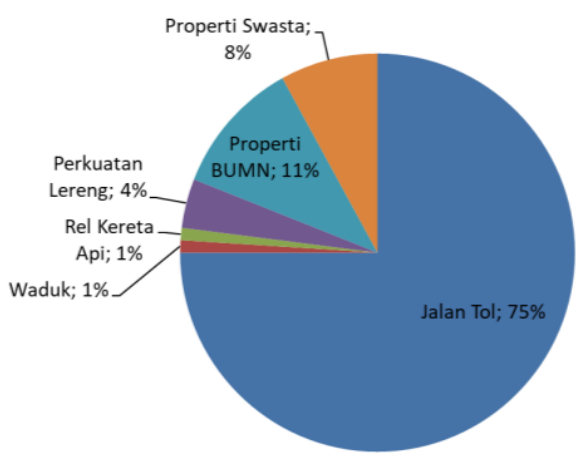

Gambar 2

Pangsa Pasar Segmentasi Geotextile di Indonesia 
Selain itu perusahaan ini juga memiliki lab tersendiri untuk menguji langsung kualitas dari produk yang telah dibuat, sehingga menambah kepercayaan dari konsumen bahwa produk yang dihasilkan memiliki kualitas yang tinggi. Lalu karena kemampuan perusahaan untuk melakukan stok produk dalam jumlah banyak dan pengiriman yang cepat, menyebabkan perusahaan - perushaan besar tertarik untuk melakukan kerja sama dengan perushaan ini. Banyaknya pesaing - pesaing yang tidak ingin meningkatkan kualitasnya menjadikan salah satu peluang bagi perusahaan untuk dapat mempromosikan produknya dan menjadi leader atau pemimpin di industri ini. Peluang lain yang dapat diambil adalah dengan menciptakan produk baru seperti produk dengan tipe 300 GSM, tentunya hal ini akan menjadikan perusahaan untuk dapat memonopoli pangsa pasar di Indonesia.

Ancaman pertama adalah munculnya produk pengganti Geotextile yang berbahan PET (Polyethylen Terephtalate), dimana produk ini digunakan untuk bendungan yang sangat besar atau bangunan yang sangat megah dan tinggi. Adanya pandemi yang menyebabkan pembangunan infrastruktur menjadi terhenti menyebabkan permintaan akan produk Geotextile menurun drastis sehingga mesin tidak berjalan dan produksi tidak dilakukan

3. Strategi Pemasaran Produk Geotextile

Strategi targeting yang cocok diterapkan pada perusahaan $\mathrm{X}$ adalah mass market production. Karena produk yang ditawarkan dapat digunakan pada segmen apa saja yang membutuhkan produk Geotextile dalam pekerjaannya. Tetapi hampir $75 \%$ market yang membutuhkan produk Geotextile adalah proyek pembangunan jalan raya dan tol sehingga permintaan akan produk tidaklah sedikit.

Target produk Geotextile adalah konsumen yang bergerak di bidang pembangunan infrastruktur yang mengedepankan kualitas produk dan teknologi yang digunakan. Tetapi menurut analisa penulis, perusahaan $\mathrm{X}$ dapat memperluas pasarnya dikarenakan apabila perusahaan $\mathrm{X}$ dapat memproduksi tipe baru diatas 250 GSM, maka aka nada kemungkinan mereka tertarik untuk menggunakan produk Geotextile dan tidak lagi menggunakan tipe 250 GSM.

Posisi produk Geotextile diantara perusahaan atau competitor lain di industri infrastruktur adalah sebagai perusahaan yang teratas. Produk Geotextile dari perushaan $\mathrm{X}$ dibuat menggunakan teknologi canggih yang telah dimodifikasi sehingga memiliki kualitas yang terbaik dibandingkan dengan perusahaan lainnya.

4. Analisa Strategi Penetrasi Pasar Geotextile

Untuk dapat suskes memasarkan dan memperbesar market share produknya di Indonesia, maka perlu dilakukan strategi marketing penetrasi pasar. Dengan menggunakan marketing mix, dapat diketahui bagaimana penetrasi pasar yang perlu dilakukan oleh perushaan $\mathrm{X}$ antara lain:

a. Product perusahaan $\mathrm{X}$ memiliki keunggalan tersendiri dalam hal kualitas dan juga kemampuan produksinya. Saat ini perusahaan X cenderung terfokus pada 3 jenis yang sudah ada di market, sebaiknya perusahaan X mengembangkan produknya lebih lanjut untuk dapat menciptakan jenis baru diatas 250 GSM dengan cara membeli alat produksi yang lebih canggih.

b. Price Geotetile, harga produk Geotextile memang terbilang mahal dan kebutuhannya dalam jumlah yang banyak menjadikan sebuah perusahaan kesulitan untuk melakukan pembayaran diawal. Untuk dapat menarik minat konsumen maka sebaiknya perusahaan menerapkan sistem kepercayaan dan loyalitas pelanggan, apabila semakin lama konsumen itu sudah berlangganan di perusahaan X maka semakin sedikit juga DP yang perlu dibayarkan

c. Promotion, Perusahaan X perlu melakukan promosi lebih luas lagi untuk mendapatkan konsumen yang belum masih belum menggunakan produk dari 
perusahaan X menggunakan media yang ada, yaitu melalui words of mouth, dengan cara menjaga baik hubungan dengan konsumen dan menanyakan masalah yang ada baik dalam produk maupun pelayanannya dan Melalui Internet karena hal ini merupakan promosi yang mudah dan biaya yang dikeluarkan juga tidak besar.

d. Placement, hingga saat ini perusahaan $\mathrm{X}$ belum memiliki kantor pemasarannya sendiri, sehingga konsumen yang berminat untuk membeli harus terlebih dahulu datang ke tempat produksi atau labnya dimana hal ini cukup memakan waktu, untuk itu perlu dilakukan tempat persediaan produk geotextile dan juga sarana informasi produk bagi konsumennya di kota - kota besar yang memiliki pelanggan dari Perusahaan X seperti Jakarta, Bandung, Surabaya.

\section{KESIMPULAN}

Berdasarkan Hasil analisa menggunakan metode SWOT analisis dan five competitive forces, maka strategi dan taktik yang tepat untuk pemasaran produk geotextile adalah menjaaga hubungan dengan konsumen. Namun belum adanya kantor pemasaran di wilayah - wilayah kota besar menjadikan konsumen harus datang langsung ke tempat produksi Geotextile. Lalu Perusahaan $\mathrm{X}$ dapat menerapkan program loyalty dikarenakan biaya dan kebutuhan produk yang tinggi menjadikan beberapa Perusahaan kesulitan dalam membeli produk Geotextile. Membuat produk baru untuk dengan tipe 300 GSM dan 350 GSM yang menggunakan teknologi yang canggih. Selain itu karena pangsa pasar yang sangat tinggi dalam hal jalan raya, tentunya hal ini akan menciptakan ketergantungan dalam bidang tersebut, sehingga Perusaaan $\mathrm{X}$ sebaiknya mengembangkan produk baru yaitu jumbo bag. Dimana proses bahan baku dan mesin yang digunakan memiliki kesamaan dengan produk jumbo bag.

\section{DAFTAR PUSTAKA}

Anggraini, A. (2009). Usulan Perumusan Strategi Perusahaandengan Analisis SWOT: Studi Kasus PT. Saung Angklung Udjo Bandung. Tesis Magister Manajemen. Universitas Padjajaran.

Firmansyah, F. \& Abdilah, K. F. (2014). Analisis SWOT dalam penentuan strategi pemasaran produk pembiayaan pada PT. Panin Bank Syariah, Tbk. kantor cabang Malang. Modernisasi, 10(2), $77-96$

Hajar, I., Mahrani, S. W., \& Sinarwati. (2014). Segmentation, targeting, positioning and strategy of radio company in Kendari, Southeast Sulawesi. International Journal of Humanities and Social Science Invention, 3, 47 - 54. IISN 2319-7714.

Kartajaya, H., \& Yuswohady, S. (2005). Attracting Tourists Traders Investors: Strategi Memasarkan Daerah di Era Otonomi.

Kotler, P., Kartajaya, H., \& Young, D. (2004). Attracting Investors: A Marketing Approach to Finding Funds for Your Business. New Jersey

McCarthy, E. J. (1985). Dasar-dasar Pemasuran. Alih Bahasa Gunawan Hutauruk. Jakarta: Penerbit Erlangga.

Porter, M. E. (2008). On Competition (Updated and expanded ed.). Boston: Harvard Business School Publishing.

Sutisna. (2002). Perilaku Konsumen dan Strategi Pemasaran. Bandung: Rosdakarya.

Vladi, E. (2014). Tourism Development strategies, SWOT analysis and improvement of Albania's Image. European Journal of Sustainable Development, 3, 167-178. ISSN: 2239-5938. 